\title{
CHRONIC HEPATITIS C: HEPATIC IRON CONTENT DOES NOT CORRELATE WITH RESPONSE TO ANTIVIRAL THERAPY
}

Patricia da Silva Fucuta PEREIRA(1), Ivonete Sandra de SOUZA E SILVA(1), Silvia Naomi de Oliveira UEHARA(1), Christini Takemi EMORI(1), Valéria Pereira LANZONI(2), Antonio Eduardo Benedito SILVA(1) \& Maria Lucia Gomes FERRAZ(1)

\begin{abstract}
SUMMARY
The complex interaction between hepatitis $\mathrm{C}$ virus infection, iron homeostasis and the response to antiviral treatment remains controversial. The aim of this study was to evaluate the influence of hepatic iron concentration (HIC) on the sustained virological response (SVR) to antiviral therapy in patients with chronic hepatitis C. A total of 50 patients who underwent pretreatment liver biopsy with assessment of HIC by graphite furnace atomic absorption spectroscopy and were subsequently submitted to antiviral treatment with interferon/peginterferon and ribavirin were included in the study. Patients with alcoholism, history of multiple blood transfusion, chronic kidney disease, hemolytic anemia and parenteral iron therapy were excluded. The iron related markers and HIC were compared between those who achieved an SVR and non-responders (NR) patients. The mean age was 45.7 years and the proportion of patients' gender was not different between SVR and NR patients. The median serum iron was 138 and $134 \mu \mathrm{g} / \mathrm{dL}(p=0.9)$, the median serum ferritin was 152.5 and $179.5 \mathrm{ng} / \mathrm{mL}(p=0.87)$ and the median HIC was 9.9 and $8.2 \mu \mathrm{mol} / \mathrm{g}$ dry tissue $(p=0.51)$, for SVR and NR patients, respectively. Thus, hepatic iron concentration, determined by a reliable quantitative method, was not a negative predictive factor of SVR in patients with chronic hepatitis C presenting mild to moderate hepatic iron accumulation.
\end{abstract}

KEYWORDS: Iron; Hepatitis C virus; Interferon; Peginterferon; Ribavirin; Liver biopsy.

\section{INTRODUCTION}

Iron is an essential element for all living organisms and the complex interaction between iron homeostasis and human viral infections remains a challenging issue ${ }^{13}$.

The association between hepatitis $\mathrm{C}$ virus (HCV) infection and altered serum iron profile or hepatic iron deposits has been evaluated in several studies $^{6,9,36}$, but the prevalence of hepatic iron overload, its relationship with the severity of disease and its influence on the response to antiviral treatment are still controversial ${ }^{14,15,27,34,35}$.

Despite marked advances in the treatment of $\mathrm{HCV}$ infection, sustained elimination of the virus is not achieved in almost half the patients even with the current combined treatment of peginterferon and ribavirin ${ }^{18}$. Several viral and host factors such as HCV genotype, age, gender and degree of fibrosis are associated with the response to treatment, but the impact of hepatic iron deposits remains uncertain. Some studies have indicated that increased hepatic iron is one of the negative predictive factors of response to treatment ${ }^{2,7,24,29,33,40}$, but this fact has not been confirmed in other investigations ${ }^{1,12,20,22,31}$. However, it must be pointed out that most of these studies had not applied adequate methods of quantifying hepatic iron.

The objective of the present study was to evaluate the influence of hepatic iron concentration (HIC) on the response to combined treatment with interferon/peginterferon and ribavirin in patients with chronic hepatitis $\mathrm{C}$ using a very accurate method of assessing hepatic iron content.

\section{PATIENTS AND METHODS}

This retrospective study identified patients with chronic hepatitis C (anti-HCV and HCV RNA positive) seen at the Hepatitis Outpatient Clinic of the Federal University of Sao Paulo, who were consecutively submitted to a pretreatment liver biopsy between May 2000 and August 2001 and evaluated regarding $\mathrm{HIC}^{38}$. Among these patients, those who received antiviral treatment with interferon/peginterferon and ribavirin were included in the present study after giving their written informed consent. The protocol conformed to the ethical guidelines of the 1975 Helsinki Declaration and was approved by the local Ethical Committee.

Exclusion criteria were alcohol consumption $>20 \mathrm{~g} /$ day, co-infection with HIV or HBV, immunosuppression, previous antiviral therapy, a history of multiple blood transfusions ( $>6$ units), chronic kidney disease, hemolytic anemia and parenteral iron therapy.

Assessment of biochemical and virological data and iron status by serum tests: Laboratory tests were carried out up to one month before or after the liver biopsy. Aspartate aminotransferase (AST, $\mathrm{U} / \mathrm{L}$ ) and alanine aminotransferase (ALT, U/L) were determined by

(1) Division of Gastroenterology, Hepatitis Section, Federal University of Sao Paulo, Sao Paulo, SP, Brazil.

(2) Department of Pathology, Federal University of Sao Paulo, Sao Paulo, SP, Brazil.

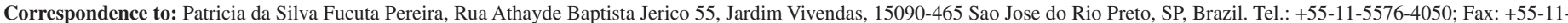
5576-4050. E-mail: patriciafucuta@gmail.com 


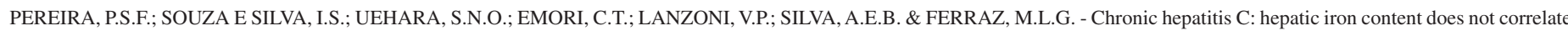
with response to antiviral therapy. Rev. Inst. Med. trop. S. Paulo, 51(6): 331-336, 2009.

an automatized kinetic method and were reported as the number of times the upper limit of normal (ULN). Serum iron (normal value: $37-145 \mu \mathrm{g} / \mathrm{dL}$ for women and $59-158 \mu \mathrm{g} / \mathrm{dL}$ for men) was measured by a colorimetric method (Olympus AU 640 Analyser, Tokyo, Japan) and serum ferritin (normal value: $5-200 \mathrm{ng} / \mathrm{mL}$ for women and 22-415 $\mathrm{ng} / \mathrm{mL}$ for men) was assayed by a chemiluminescence immunoassay (Access 2 Immunoassay System, Beckman Coulter Inc., Fullerton, CA, USA). Serum transferrin (normal value: $200-400 \mathrm{mg} / \mathrm{dL}$ ) was determined by immunoturbidimetry (Olympus AU 640 Analyser, Tokyo, Japan) and its saturation was calculated using the following formula ${ }^{39}$ : iron/transferrin x 71.2.

HCV RNA was detected by qualitative PCR using Amplicor kits (Cobas Amplicor HCV Test, Roche Diagnostic System, USA; detection limit: $50 \mathrm{IU} / \mathrm{mL}$ ) and $\mathrm{HCV}$ genotyping was performed by sequencing the NS5B region of $\mathrm{HCV}^{30}$.

Evaluation of hepatic iron concentration in liver tissue: The quantification of iron in liver tissue was performed according to the modified method described by OLYNYK et al. ${ }^{28}$. To measure HIC, fresh liver specimens placed in a clean tube were dried to constant weight in a vacuum oven at $52^{\circ} \mathrm{C}$. The dried samples were then weighed and placed in a tube containing $1 \mathrm{~mL}$ concentrated nitric acid and $1 \mathrm{~mL}$ ion-free water. Next the samples were digested in a microwave digestion system (MDS 2000, USA). A blank and samples of bovine liver used as a reference material (1577b) were treated similarly. The resulting solutions were transferred to volumetric flasks and made up with ion-free water. All digested samples were diluted $1: 8$ in $0.2 \%$ nitric acid and a $10-\mu \mathrm{L}$ volume was injected into the furnace for measurement. Iron concentration was determined by graphite furnace atomic absorption spectroscopy using a Varian Perkin-Elmer SIMAA-6000 spectrometer (USA). The results were expressed as $\mu \mathrm{mol} / \mathrm{g}$ dry tissue weight. The hepatic iron index (HII), defined as the HIC to age ratio ${ }^{3}$, was also calculated.

Antiviral treatment of chronic hepatitis C: Treatment was indicated for patients with a degree of fibrosis $\geq 2$ (Metavir classification ${ }^{4}$ ) in liver biopsies and consisted of combined administration of standard interferon (3MU three times weekly) or peginterferon $(\alpha 2 \mathrm{~b} 1.5 \mu \mathrm{g} / \mathrm{kg}$ or $\alpha 2 \mathrm{a} 180 \mu \mathrm{g}$ once-weekly) plus ribavirin (body weight $<75 \mathrm{~kg}: 1.0 \mathrm{~g} /$ day; $\geq 75 \mathrm{~kg}: 1.25 \mathrm{~g} /$ day) for 24 to 48 weeks, according to the genotype.

Comparative analysis according to the response to treatment: The response to antiviral treatment was evaluated by the detection of HCV RNA in serum by qualitative PCR at the end of treatment and six months thereafter. Patients who tested HCV RNA negative in the sixth month post-treatment were classified as responders (sustained virological response, SVR). All other patients, including those who relapsed, were classified as non-responders (NR). The patients were compared regarding hepatic iron concentration (HIC) and serum iron profile according to the response to treatment (SVR or NR).

Statistical analysis: The results were first reported descriptively and then the association between variables of interest was investigated. Continuous variables were compared by the Student t-test or MannWhitney test when appropriate. Categorical variables were compared using the chi-square test. A $p$ value of less than 0.05 was considered statistically significant. Statistical analysis was performed by PASW Statistics 17.0 (SPSS Inc., Chicago, IL).

\section{RESULTS}

Among the 96 patients evaluated regarding HIC (previously reported results $^{38}$ ), 50 underwent antiviral treatment for chronic hepatitis C (39 with interferon + ribavirin and 11 with peginterferon + ribavirin) and were included in the present study. The mean age was 45.7 years (28-70), the mean duration of $\mathrm{HCV}$ infection was 20 years and there was predominance of male gender (60\%). Hepatitis $\mathrm{C}$ virus genotyping was performed for 35 patients and resulted in type 1 in 27 (77\%) and type 3 in eight (23\%). Sustained virological response was achieved in 18 patients (36\%). Among patients infected with HCV genotype 1 and 3, the rates of sustained virological response were $26 \%$ and $25 \%$, respectively $(p>0.05)$. Proportion of patients' gender was not significantly different between SVR and NR patients (female/male: 7/11 vs 13/19, respectively, $p=0.90$ ).

The demographic and clinical characteristics of the patients are shown in Table 1.

Table 1

Demographic and clinical characteristics of the sample studied

Characteristics $n=50$

Sex

Male/female

$30 / 20$

Age (years)

$45.7 \pm 10.2$

Duration of HCV infection (years)

$20.4 \pm 8.8$

HCV genotype (\%)

Type 1

Type 3

Histology

Fibrosis stage 3/4 Metavir (\%) 20

Hemoglobin (g/dL)

$14.8 \pm 1.1$

Hematocrit (\%)

$45.0 \pm 3.2$

Platelet count $\left(\mathrm{x} 10^{4} / \mathrm{mm}^{3}\right)$

$18.5 \pm 6.0$

ALT (xULN)

$2.4(1.6-3.4)$

AST (xULN)

$1.8(1.5-2.8)$

Serum iron $(\mu \mathrm{g} / \mathrm{dL})$

$136.5(104.0-162.2)$

Serum ferritin $(\mathrm{ng} / \mathrm{mL})$

$164.0(86.9-352.0)$

Serum transferrin (mg/dL)

$310.6 \pm 50.1$

Transferrin saturation (\%)

$33.5 \pm 13.2$

HIC ( $\mu \mathrm{mol} / \mathrm{g}$ dry tissue)

$8.4(4.8-13.3)$

Hepatic iron index

$0.18(0.09-0.36)$

Quantitative variables are expressed as mean \pm SD or median (interquartile range). $\mathrm{HCV}$, hepatitis $\mathrm{C}$ virus; $\mathrm{ALT}$, alanine aminotransferase; ULN, upper limit of normal; AST, aspartate aminotransferase; HIC, hepatic iron concentration. 


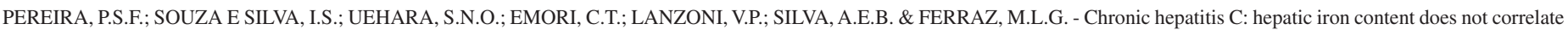
with response to antiviral therapy. Rev. Inst. Med. trop. S. Paulo, 51(6): 331-336, 2009.

Table 2

Serum and hepatic iron profiles in patients presenting a sustained virological response (SVR) and in non-responders (NR)

\begin{tabular}{lccc}
\hline & SVR & NR & $p$ \\
\hline Serum iron $(\mu \mathrm{g} / \mathrm{dL})$ & $138(120.5-151.7)$ & $134(100.2-162.7)$ & 0.90 \\
Ferritin $(\mathrm{ng} / \mathrm{mL})$ & $152.5(93.6-326.5)$ & $179.5(81.6-352.0)$ & 0.87 \\
Transferrin $(\mathrm{mg} / \mathrm{dL})$ & $315.2 \pm 43.0$ & $308.1 \pm 54.3$ & 0.46 \\
Transferrin saturation $(\%)$ & $32.5 \pm 12.7$ & $34.0 \pm 13.6$ & 0.69 \\
HIC $(\mu \mathrm{mol} / \mathrm{g}$ dry tissue $)$ & $9.9(4.2-18.7)$ & $8.2(4.9-11.3)$ & 0.51 \\
\hline
\end{tabular}

Quantitative variables are expressed as mean \pm SD or median (interquartile range). HIC, hepatic iron concentration.

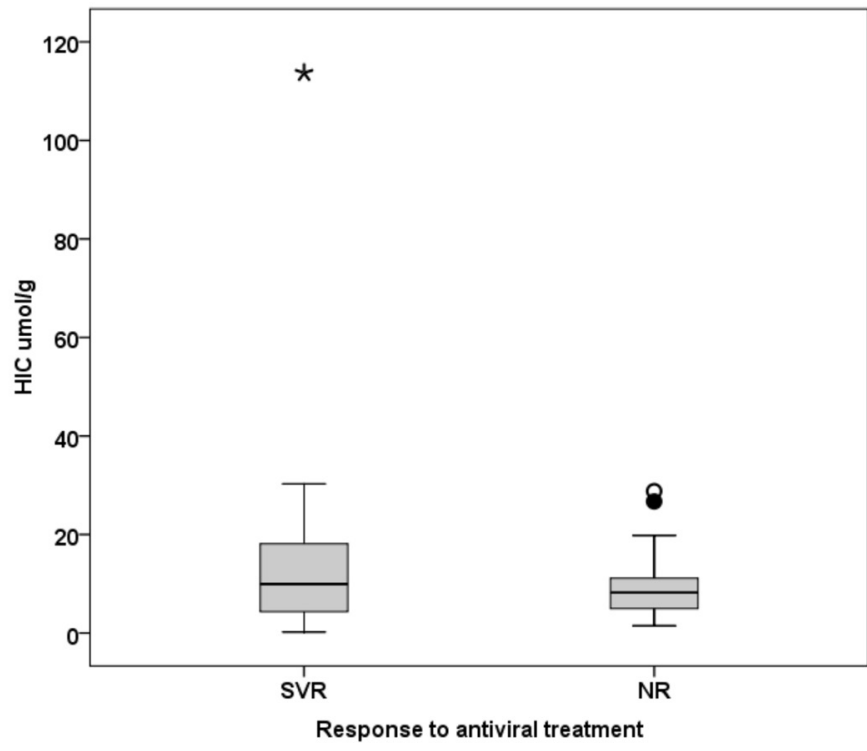

Fig. 1 - Comparison of hepatic iron concentration between patients presenting sustained virological response and non-responders.

HIC, hepatic iron concentration; SVR, sustained virological response; NR, non-responders; $*$ A 60 -year-old woman with hepatic iron concentration of $113.7 \mu \mathrm{mol} / \mathrm{g}$; OA 33-year-old man with hepatic iron concentration of $28.8 \mu \mathrm{mol} / \mathrm{g}$; $\bullet$ A 33-year-old man with hepatic iron concentration of $26,7 \mu \mathrm{mol} / \mathrm{g}$.

No difference was observed in serum iron, serum ferritin and transferrin saturation between responders and non-responders. HIC did not influence the SVR rate (Fig. 1). Table 2 shows the serum and hepatic iron profile of responders and non-responders patients.

\section{DISCUSSION}

Chronic hepatitis $\mathrm{C}$ has been associated with the accumulation of iron in the liver, which could interfere with the response to antiviral treatment. However, studies evaluating the effect of iron on treatment in this population are extremely conflicting in terms of the method used for the determination of hepatic iron content, the adopted therapeutic regimen and the evaluation of response to treatment.

In the present investigation, the gold standard for the evaluation of HIC was adopted, i.e., quantification of iron in liver tissue specimens and the adopted antiviral therapy included either standard interferon or peginterferon, both with ribavirin. The results demonstrated that severe iron overload was a rare event among HCV-infected patients and HIC was not associated with the SVR to treatment with interferon/ peginterferon plus ribavirin. In fact, hepatic iron content has been shown to be low in most patients infected with $\mathrm{HCV}^{8,17,25}$. In the present study, patients with possible other causative factors of iron deposition, such as multiple blood transfusion and hemolytic anemia were excluded. Thus, our results reflect the HIC in patients infected with HCV without confounding factors of secondary iron overload. Moreover, the proportion of patients' gender was similar between responders and non-responders and thus it is unlikely that the distinct serum and hepatic iron profiles between men and women have influenced the present analysis. The lack of association between HCV genotypes and the rate of SVR observed in our study is likely due to the low number of patients with this analysis available.

Early studies regarding HIC and monotherapy with standard interferon have only evaluated the impact on the biochemical response. VAN THIEL et al. ${ }^{40}$ studied 79 patients treated with interferon for six months and showed that the biochemical response (defined as complete normalization of ALT) or partial response (defined as a $>50 \%$ reduction in ALT levels six months after the end of treatment) was worse in patients with a higher HIC. Soon thereafter, in 1995, BARTON et al. ${ }^{2}$ found that the pattern of iron distribution in the liver was significantly different between patients with and without a complete biochemical response, also defined as normalization of ALT. OLYNYK et al. ${ }^{29}$ reported higher HIC in biochemical non-responders to interferon therapy for six months than in those with good response. Similar findings were reported by PIPERNO et al. ${ }^{33}$, who observed an association between higher hepatic iron content and a poor biochemical response in patients with chronic hepatitis $\mathrm{C}$ treated with standard interferon for 12 months. It should be emphasized that $80 \%$ of the patients with elevated HIC presented genotype $1 \mathrm{~b}$. Also in that study, iron depletion by phlebotomy performed on 16 patients subsequently treated with interferon did not improve the response to treatment despite improvement of ALT levels.

On the other hand, studies evaluating virological response and hepatic iron determined by histological semiquantification have reported conflicting data. The results obtained in a group of patients with low levels $(<1 \mathrm{mEq} / \mathrm{mL})$ of HCV RNA ${ }^{1}$ treated with interferon for 24 weeks, showed higher iron-staining score in virological responders than in nonresponders and the investigators hypothesized that an optimal range of iron concentration may be beneficial for immune response. In contrast, 


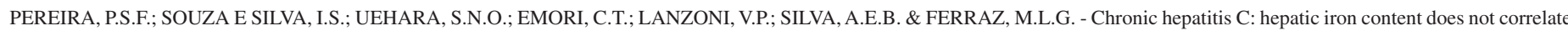
with response to antiviral therapy. Rev. Inst. Med. trop. S. Paulo, 51(6): 331-336, 2009.

FUJITA et al. ${ }^{16}$ observed a significantly higher histological total iron score in patients not responding to combined interferon and ribavirin and LIN et $a l .{ }^{24}$ found that positive hepatic iron stain predicted non-response to peginterferon and ribavirin therapy.

However, when hepatic iron levels were actually measured, recent publications ${ }^{12,22,31}$ did not find any influence of HIC on the SVR in patients undergoing combined therapy with standard interferon and ribavirin.

To the best of our knowledge, only one study ${ }^{20}$ has previously evaluated the role of hepatic iron concentration (measured by atomic absorption spectrophotometry) in relation to the efficacy of chronic hepatitis $\mathrm{C}$ therapy schedule including peginterferon. In agreement with our results, HOFER et al. ${ }^{20}$ observed no difference in tissue iron concentration between patients who achieved an SVR and non-responders both submitted to combined interferon/peginterferon and ribavirin treatment.

Even in cases of iron overload, as in thalassemic patients, two studies ${ }^{11,37}$ found no impact of excessive iron deposition on the SVR rate. In addition, demonstrating the efficacy of combined treatment with peginterferon and ribavirin in young thalassemic patients, one study ${ }^{21}$ showed an SVR in $62.5 \%$ of cases, a rate similar to that observed in non-thalassemic patients.

The role of HFE genotype on hepatic iron in chronic hepatitis $\mathrm{C}$ is another interesting area of investigation. This issue has been addressed in several studies and controversial findings have been reported ${ }^{32}$. CORENGIA et al. ${ }^{8}$ studied 206 patients with chronic hepatitis $\mathrm{C}$ and found higher frequency of genotypes containing HFE mutations in the subgroup of patients with hepatic iron accumulation, whereas no significant difference was observed between the subgroup of patients without hepatic iron deposits and control subjects. They also demonstrated a significant association between $H F E$ genotypes and iron deposition in hepatocellular compartment, but not in sinusoidal and portal areas, suggesting that the cause of hepatic iron accumulation in chronic hepatitis $\mathrm{C}$ could not be simply the release of iron from necrotic hepatocytes or the inflammatory-mediated perturbation of iron trafficking, when iron would accumulate preferentially in Kupffer cells.

But in another study, KAZEMI-SHIRAZI et al. ${ }^{23}$ assessed the HFE mutations in 184 patients with chronic hepatitis $\mathrm{C}$ and 487 controls and found no difference in hepatic iron content among patients with or without HFE mutations. In hepatitis C and control group, 32\% and $29 \%$ of patients carried either mutations (C282Y and H63D), respectively. Histological iron grades 3 or 4 (Perls' Prussian blue stain) were found in $23.4 \%$ and $15.7 \%$ of chronic hepatitis $C$ patients with and without mutation of the $H F E$ gene, respectively, $p=0.36$.

Interestingly, recent data ${ }^{5}$ from patients with advanced fibrosis (part of the HALT-C study) showed that the presence of mutations in the HFE gene (especially the most common H63D mutation) resulted in a higher chance of an SVR during retreatment with peginterferon and ribavirin, with the observation of a direct correlation with ferritin and semiquantified histological iron levels. Although we did not investigate mutations of hereditary hemochromatosis in this study, none of the patients presented an HII suggestive of this disease, i.e., higher than $1.9^{3}$. In addition, there is evidence indicating that the prevalence of this disease among patients infected with HCV does not differ from that found in the general population ${ }^{23,26}$.

The lack of a correlation between HIC and response of patients with hepatitis $\mathrm{C}$ to antiviral treatment agrees with the majority of the results regarding phlebotomy as coadjuvant treatment ${ }^{7,10,19}$. DI BISCEGLIE et $a l .{ }^{10}$ showed that in patients with hepatitis $\mathrm{C}$ not responding to interferon monotherapy iron depletion by phlebotomy did not result in a higher SVR rate during retreatment, despite an association with improved liver injury manifested by a decrease in transaminases and improved liver histopathology after phlebotomy. Similarly, in the study of HERRERA ${ }^{19}$ iron depletion by phlebotomy did not improve SVR in the retreatment of patients who were previously non-responders. But on the contrary, in the study of CARLO et al..$^{7} 83$ patients were randomly assigned to be submitted to iron depletion before interferon monotherapy and a better complete response (biochemical and virological) was achieved in the phlebotomy group.

In conclusion, hepatic iron concentration determined by a reliable quantitative method, was not a negative predictive factor of SVR to antiviral treatment with interferon/peginterferon and ribavirin in patients with chronic hepatitis $\mathrm{C}$ presenting mild to moderate hepatic iron accumulation.

\section{RESUMO}

\section{Hepatite C crônica: concentração hepática de ferro não é correlacionada com a resposta ao tratamento antiviral}

A complexa interação entre infecção pelo vírus da hepatite $C$, homeostase do ferro e resposta ao tratamento antiviral permanece controversa. O objetivo deste estudo foi avaliar a influência da concentração hepática de ferro (CHF) na resposta virológica sustentada (RVS) à terapia antiviral na hepatite $\mathrm{C}$ crônica. Foram incluídos 50 pacientes que foram submetidos à biopsia hepática pré-tratamento com determinação da CHF por espectrofotometria de absorção atômica com forno de grafite e tratados posteriormente com interferon/peginterferon e ribavirina. Pacientes com alcoolismo, história de múltiplas transfusões sanguíneas, doença renal crônica, anemia hemolítica e terapia com ferro parenteral foram excluídos. O perfil de ferro sérico e a CHF foram comparados entre aqueles que atingiram RVS e os não-respondedores (NR). A média de idade dos pacientes foi 45,7 anos e não houve diferença na proporção de homens e mulheres entre os grupos RVS e NR. A mediana do ferro sérico foi 138 and $134 \mu \mathrm{g} / \mathrm{dL}(p=0.9)$, a mediana da ferritina sérica foi 152,5 e $179,5 \mathrm{ng} / \mathrm{mL}(p=0,87)$ e a CHF mediana foi 9,9 e $8,2 \mu \mathrm{mol} / \mathrm{g}$ de tecido seco $(p=0,51)$, para pacientes com RVS e NR, respectivamente. Concluindo, a concentração hepática de ferro, determinada por um método quantitativo confiável, não foi um fator preditivo negativo de RVS em pacientes com hepatite C crônica e acúmulo de ferro hepático leve a moderado.

\section{ACKNOWLEDGMENTS}

The hepatic iron quantification was performed at Chemistry Institute and Institute of Nuclear Energy and Research, University of Sao Paulo School of Medicine, Sao Paulo, Brazil and we are grateful to Dr. Pedro V. Oliveira, Dr. Maria I. Cantagalo and Dr. Elizabete Dantas for their relevant contribution. 


\section{REFERENCES}

1. AKIYOSHI, F.; SATA, M.; UCHIMURA, Y.; SUZUKI, H. \& TANIKAWA, K. - Hepatic iron stainings in chronic hepatitis C patients with low HCV RNAlevels: a predictive marker for IFN therapy. Amer. J. Gastroent., 92: 1463-1466, 1997.

2. BARTON, A.L.; BANNER, B.F.; CABLE, E.E. \& BONKOVSKY, H.L. - Distribution of iron in the liver predicts the response of chronic hepatitis $\mathrm{C}$ infection to interferon therapy. Amer. J. clin. Path., 103: 419-424, 1995.

3. BASSETT, M.L.; HALLIDAY, J.W. \& POWELL, L.W. - Value of hepatic iron measurements in early hemochromatosis and determination of the critical iron level associated with fibrosis. Hepatology, 6: 24-29, 1986.

4. BEDOSSA, P. \& POYNARD, T. - An algorithm for the grading of activity in chronic hepatitis C. The Metavir Cooperative Study Group. Hepatology, 24: 289-293, 1996.

5. BONKOVSKY, H.L.; NAISHADHAM, D.; LAMBRECHT, R.W. et al. - Roles of iron and HFE mutations on severity and response to therapy during retreatment of advanced chronic hepatitis C. Gastroenterology, 131: 1440-1451, 2006.

6. BOUCHER, E.; BOURIENNE, A.; ADAMS, P. et al. - Liver iron concentration and distribution in chronic hepatitis $\mathrm{C}$ before and after interferon treatment. Gut, $\mathbf{4 1}$ : 115-120, 1997.

7. CARLO, C.; DANIELA, P. \& GIANCARLO, C. - Iron depletion and response to interferon in chronic hepatitis C. Hepatogastroenterology, 50: 1467-1471, 2003.

8. CORENGIA, C.; GALIMBERTI, S.; BOVO, G. et al. - Iron accumulation in chronic hepatitis C: relation of hepatic iron distribution, HFE genotype, and disease course. Amer. J. clin. Path., 124:846-853, 2005.

9. Di BISCEGLIE, A.M.; AXIOTIS, C.A.; HOOFNAGLE, J.H. \& BACON, B.R. Measurements of iron status in patients with chronic hepatitis. Gastroenterology, 102: 2108-2113, 1992.

10. DI BISCEGLIE, A.M.; BONKOVSKY, H.L.; CHOPRA, S. et al. - Iron reduction as an adjuvant to interferon therapy in patients with chronic hepatitis $\mathrm{C}$ who have previously not responded to interferon: a multicenter, prospective, randomized, controlled trial. Hepatology, 32: 135-138, 2000

11. DI MARCO, V.; LO IACONO, O.; ALMASIO, P. et al. - Long-term efficacy of alphainterferon in beta-thalassemics with chronic hepatitis C. Blood, 90: 2207-2212, 1997.

12. DISTANTE, S.; BJORO, K.; HELLUM, K.B. et al. - Raised serum ferritin predicts non-response to interferon and ribavirin treatment in patients with chronic hepatitis C infection. Liver, 22: 269-275, 2002.

13. DRAKESMITH, H. \& PRENTICE, A. - Viral infection and iron metabolism. Nature Rev. Microbiol., 6: 541-552, 2008.

14. FABRIS, C.; TONIUTTO, P.; SCOTT, C. et al. - Serum iron indices as a measure of iron deposits in chronic hepatitis C. Clin. Chem. Acta, 304: 49-55, 2001.

15. FARINATI, F.; CARDIN, R.; DE MARIA, N. et al. - Iron storage, lipid peroxidation and glutathione turnover in chronic anti-HCV positive hepatitis. J. Hepat., 22: 449-456, 1995 .

16. FUJTA, N.; SUGIMOTO, R.; URAWA, N. et al. - Hepatic iron accumulation is associated with disease progression and resistance to interferon/ribavirin combination therapy in chronic hepatitis C. J. Gastroent. Hepat., 22: 1886-1893, 2007.

17. GUYADER, D.; THIROUARD, A.S.; ERDTMANN, L. et al. - Liver iron is a surrogate marker of severe fibrosis in chronic hepatitis C. J. Hepat., 46: 587-595, 2007.

18. HEATHCOTE, E. - Antiviral therapy: chronic hepatitis C. Review. J. viral Hepatitis, 14: $82-88,2007$
19. HERRERA, J.L. - Iron depletion is not effective in inducing a virologic response in patients with chronic hepatitis $\mathrm{C}$ who failed to respond to interferon therapy. Amer. J. Gastroent., 94: 3571-3575, 1999.

20. HOFER, H.; OSTERREICHER, C.; JESSNER, W. et al. - Hepatic iron concentration does not predict response to standard and pegylated-ifn/ribavirin therapy in patients with chronic hepatitis C. J. Hepat., 40: 1018-1022, 2004.

21. INATI, A.; TAHER, A.; GHORRA, S. et al. - Efficacy and tolerability of peginterferon alpha-2a with or without ribavirin in thalassaemia major patients with chronic hepatitis C virus infection. Brit. J. Haemat., 130: 644-646, 2005.

22. JURCZYK, K.; KARPINSKA, E.; WAWRZYNOWICZ-SYCZEWSKA, M. et al. - State of the iron metabolism in patients with chronic hepatitis $\mathrm{C}$ type $\mathrm{C}$ does not influence antiviral treatment with interferon and ribavirin. Hepatogastroenterology, 55: 557$561,2008$.

23. KAZEMI-SHIRAZI, L.; DATZ, C.; MAIER-DOBERSBERGER, T. et al. - The relation of iron status and hemochromatosis gene mutations in patients with chronic hepatitis C. Gastroenterology, 116: 127-134, 1999.

24. LIN, T.J.; LIAO, L.Y.; LIN, C.L.; CHANG, T.A. \& LIU, S.O. - Hepatic iron influences responses to combination therapy with peginterferon alfa and ribavirin in chronic hepatitis C. Hepatogastroenterology, 55: 1412-1415, 2008.

25. MARTINELLI, A.L.; RAMALHO, L.N. \& ZUCOLOTO, S. - Hepatic stellate cells in hepatitis $C$ patients: relationship with liver iron deposits and severity of liver disease. J. Gastroent. Hepat., 19: 91-98, 2004.

26. MARTINELLI, A.L.; ZAGO, M.A.; ROSELINO, A.M. et al. - Porphyria cutanea tarda in Brazilian patients: association with hemochromatosis $\mathrm{C} 282 \mathrm{Y}$ mutation and hepatitis C virus infection. Amer. J. Gastroent., 95: 3516-3521, 2000.

27. METWALLY, M.A.; ZEIN, C.O. \& ZEIN, N.N. - Clinical significance of hepatic iron deposition and serum iron values in patients with chronic hepatitis $\mathrm{C}$ infection. Amer. J. Gastroent., 99: 286-291, 2004.

28. OLYNYK, J.; WILLIAMS, P.; FUDGE, A. et al. - Fine-needle aspiration biopsy for the measurement of hepatic iron concentration. Hepatology, 15: 502-506, 1992.

29. OLYNYK, J.K.; REDDY, K.R.; DI BISCEGLIE, A.M. et al. - Hepatic iron concentration as a predictor of response to interferon alfa therapy in chronic hepatitis C. Gastroenterology, 108: 1104-1109, 1995.

30. PEREZ, R.M.; FERRAZ, M.L.; FIGUEIREDO, M.S. et al. - Unexpected distribution of hepatitis $\mathrm{C}$ virus genotypes in patients on hemodialysis and kidney transplant recipients. J. med. Virol., 69: 489-494, 2003.

31. PIANKO, S.; McHUTCHISON, J.G.; GORDON, S.C. et al. - Hepatic iron concentration does not influence response to therapy with interferon plus ribavirin in chronic $\mathrm{HCV}$ infection. J. Interferon Cytokine Res., 22: 483-489, 2002.

32. PIPERNO, A.; SAMPIETRO, M.; D'ALBA, R. et al. - Iron stores, response to alphainterferon therapy, and effects of iron depletion in chronic hepatitis C. Liver, 16: 248-254, 1996.

33. RIGAMONTI, C.; ADORNO, S.; MADULI, E. et al. - Gender and liver fibrosis in chronic hepatitis: the role of iron status. Aliment. Pharmacol. Ther., 21: 1445-1451, 2005.

34. RIGAMONTI, C.; ANDORNO, S.; MADULI, E. et al. - Iron, hepatic stellate cells and fibrosis in chronic hepatitis C. Europ. J. clin. Invest., 32(suppl. 1): 28-35, 2002

35. SHAN, Y.; LAMBRECHT, R. \& BONKOVSKY, H. - Association of hepatitis C virus infection with serum iron status: analysis of data from the third national health and nutrition examination survey. Clin. infect. Dis., 40: 834-841, 2005.

36. SIEVERT, W.; PIANKO, S.; WARNER, S. et al. - Hepatic iron overload does not prevent a sustained virological response to interferon-alpha therapy: a long term follow-up study in hepatitis C-infected patients with beta thalassemia major. Amer. J. Gastroent., 97: 982-987, 2002. 
PEREIRA, P.S.F.; SOUZA E SILVA, I.S.; UEHARA, S.N.O.; EMORI, C.T.; LANZONI, V.P.; SILVA, A.E.B. \& FERRAZ, M.L.G. - Chronic hepatitis C: hepatic iron content does not correlate with response to antiviral therapy. Rev. Inst. Med. trop. S. Paulo, 51(6): 331-336, 2009.

37. SILVA, I.S.; PEREZ, R.M.; OLIVEIRA, P.V. et al. - Iron overload in patients with chronic hepatitis C virus infection: clinical and histological study. J. Gastroent. Hepat., 20: $243-248,2005$

38. TURATI, C.; TURSINI, P.; FRANZINI, C. et al. - Saturazione della transferrina del siero e sovraccarico di ferro. Biochim. clin., 21: 10-15, 1997.
39. VAN THIEL, D.H.; FRIEDLANDER, L.; FAGIUOLI, S. et al. - Response to interferon alpha therapy is influenced by the iron content of the liver. J. Hepat., 20: 410-415, 1994.

Received: 20 May 2009

Accepted: 28 October 2009 